\title{
PENGARUH PELATIHAN SHALAT KHUSYUK UNTUK MENGENDALIKAN PERILAKU SEKSUAL PRANIKAH PADA MAHASISWA YANG BERPACARAN
}

\section{THE INFLUENCE FERVENT PRAYER TRAINING TO REDUCE PREMARITAL SEXUAL BEHAVIOR ON DATING UNIVERSITY STUDENTS}

\author{
Patricia Intan Suri \\ Fakultas Psikologi dan Ilmu Sosial Budaya Universitas Islam Indonesia Yogyakarta \\ Email: pariciaintansuri@yahoo.com \\ Koentjoro \\ Fakultas Psikologi Universitas Gadjah Mada Yogyakarta
}

\begin{abstract}
The study was based on a hypotheses that The fervent prayer training influenced to reduce premarital sexual behavior in dating students of University $X$. The fervent prayer training is awareness efforts and practice praying fervently to restore mental awareness to be enlightened soul and avoid negative impulse, such as premarital sexual impulse. The study was based on action research with participants of the study consisted of 4 students, they were between 19 and 21 years of age. The design of the research using one group pretestposttest design. The effectiveness of intervention was evaluated by using quantitative method and descriptive analysis based on interviews and observation. The study method using one-group pretestposttest design. Before training participants received premarital sexual behavior scale and frevent prayer scale. Data from the group was analyzed with wilcoxon signed rank. The result of the study showed a score of pretest and posttest as much as $Z=-1.826$ sig 0,068 (nilai sig $>0,05$ ), this result indicating there is significant diferrences in premarital sexual behavior level before and after salat training. The result showed lower level of premarital sexsual behavior level after fervent prayer. Based on the result was concluded that the fervent prayer training was influenced to reduce premarital sexual behavior of dating students on University $X$.
\end{abstract}

Key Word: Premarital sexual behavior, prayer, praying fervently

\begin{abstract}
Abstrak
Penelitian ini bertujuan untuk mengetahui pengaruh pelatihan shalat khusyuk untuk mengurangi perilaku seksual pranikah pada mahasiswa yang berpacaran di Universitas X. Pelatihan shalat khusyuk adalah upaya penyadaran dan latihan shalat dengan khusyuk untuk mengembalikan kesadaran jiwa sehingga menjadi jiwa yang tercerahkan dan mampu mengendalikan dorongan negatif, seperti nafsu seksual pranikah. Penelitian ini merupakan penelitian action research dengan peserta penelitian terdiri atas 4 orang mahasiswa yang berusia antara 19 hingga 21 tahun. Efektivitas intervensi dievaluasi dengan metode kuantitatif dan analisis deskriprif berdasarkan hasil observasi dan wawancara. Penelitian ini menggunakan desain eksperimen onegroup pretest-posttest design, dengan analisis prates - pascates. Sebelum pelatihan, peserta menerima skala perilaku seksual pranikah dan skala shalat khusyuk untuk skrining peserta pelatihan. Data penelitian dianalisis dengan wilcoxon signed rank. Hasil dari penelitian ini adalah ketika prates dan pascates memiliki nilai Z sebesar -1.826 dengan sig 0,068 (nilai sig $>0,05$ ). Hal ini menunjukkan bahwa terdapat perbedaan yang bermakna tingkat perilaku seksual pranikah subjek sebelum dan sesudah diberikan pelatihan shalat khusyuk. Berdasarkan hasil penelitian ini dapat disimpulkan bahwa pelatihan shalat khusyuk memiliki pengaruh dalam mencegah perilaku seksual pranikah pada mahasiswa yang berpacaran di Universitas X.

Kata kunci: Perilaku seksual pranikah, shalat khusyuk.
\end{abstract}


Perilaku seksual pranikah pada remaja menjadi isu yang populer dalam masyarakat dewasa ini, karena jumlah kasus yang semakin hari semakin meningkat. Berdasarkan hasil penelitian Cook, Erdman, dan Dickens (2007) diketahui bahwa di negara-negara berkembang, lebih dari 14 juta remaja melahirkan setiap tahunnya dengan 13\% angka kematian terjadi pada ibu akibat dari kehamilan yang tidak diinginkan. Fenomena tersebut juga terjadi di kota Yogyakarta. Hasil penelitian yang dilakukan oleh Soetjiningsih (2008) terhadap 389 subjek siswa SMA di Yogyakarta yang berusia antara 15-18 tahun menunjukan bahwa sebanyak $4.77 \%$ remaja melakukan hubungan seksual pertama kali pada usia 15-18 tahun, 60\% subjek menyatakan bahwa tingkat perilaku seksual yang boleh dilakukan sebelum menikah adalah sampai dengan ciuman bibir sambil berpelukan.

Badan Pemberdayaan Perempuan dan Masyarakat Propinsi Yogyakarta (2011) menemukan bahwa kehamilan yang disebabkan oleh hubungan seksual pranikah mencapai $10.53 \%$ dan terdapat beberapa perilaku berpacaran yang dilakukan remaja, antara lain $88.70 \%$ remaja berpegangan tangan dan berpelukan; $49.17 \%$ remaja berciuman bibir; $13.29 \%$ remaja pernah melakukan masturbasi/onani; serta $10.10 \%$ remaja pernah melakukan hubungan seksual (52\% laki-laki dan $48 \%$ perempuan, dan usia termuda adalah 12 tahun sebanyak $12.7 \%$ ).

Hal serupa juga ditemukan oleh peneliti melalui hasil studi pendahuluan (survei awal) yang dilakukan kepada 100 orang mahasiswa universitas swasta di Yogyakarta. Hasilnya menunjukan bahwa 90\% mahasiswa pernah berpelukan dengan lawan jenis (teman atau pacar), 93\% mahasiswa pernah saling memegang tangan dan mencium pipi dengan lawan jenis, $77 \%$ mahasiswa pernah melakukan ciuman bibir, mahasiswa $16 \%$ pernah melakukan petting dan 8\% mahasiswa pernah melakukan hubungan seksual. Hasil survei awal tersebut menunjukkan persentase yang cukup memprihatinkan. Lebih dari $75 \%$ remaja menunjukkan indikasi perilaku seksual beresiko. Hal ini ditunjukkan oleh perilaku seksual yang muncul, seperti berpelukan, berciuman bibir, melakukan petting hingga melakukan hubungan seksual (sexual intercourse).

Perilaku seksual pranikah yang dilakukan remaja dapat mempunyai efek beruntun yang dapat menghambat perkembangan dan kesehatan remaja tersebut. Maher (2004) mengemukakan efek tersebut antara lain rasa salah atau berdosa, menyesal, harga diri rendah, emosi negatif, kehamilan tidak diinginkan, rentan terhadap penyakit menular seksual, HIV/AIDS, dan aborsi. Untuk menghindari dampak negatif yang lebih buruk dan berkepanjangan penting dilakukan sebuah intervensi untuk mencegah agar remaja tidak terjebak di dalam perilaku seksual beresiko. Intervensi yang dilakukan untuk mengatasi permalasahan meningkatnya perilaku seksual beresiko remaja perlu memperhatikan faktor penyebabnya agar intervensi yang dilakukan efektif dan tepat sasaran. 
Berbagai studi telah mengungkap faktor-faktor yang menyebabkan terjadinya perilaku seksual pranikah berasal dari dalam diri maupun dari luar diri remaja. Sarwono (2002) mengungkapkan bahwa salah satu faktor yang mengarahkan pada perilaku seksual pranikah adalah kurangnya penanaman norma agama dan pendidikan moral dalam keluarga. Selaras dengan hal tersebut, Soetjiningsih (2008) juga mengungkapkan bahwa salah satu faktor yang memengaruhi terjadinya perilaku seksual pranikah di kalangan remaja adalah rendahnya tingkat religiositas. Tinjauan beberapa studi lainnya menunjukan bahwa religiositas mempunyai kaitan dengan penundaan terjadinya hubungan seksual pada remaja. Penelitian Odimegwu (2005), Laksamana (2003), dan Meier (2003) menunjukkan bahwa religiositas merupakan faktor yang sangat penting dalam memprediksi sikap dan perilaku seksual pranikah. Bahkan menurut Donauhue dan Benson (1995), religiositas mengurangi kemungkinan terjadinya perilaku seksual pranikah remaja sebanyak $50 \%$.

Religiositas adalah tingkat keterikatan agama seseorang yang dicerminkan dalam keyakinan, pengalaman, tingkah laku, yang menunjuk kepada aspek kualitas dari manusia yang beragama untuk menjalani kehidupan sehari-hari dengan baik. Religiositas merupakan jenis dan tingkat aktivitas yang berhubungan dengan agama, seperti frekuensi berdoa, mengunjungi tempat ibadah dan keaktifan atau keanggotaan dalam kegiatan agama (Suryoputro, 2006). Salah satu dimensi religiositas menurut Glock dan Stark
(Ancok \& Suroso, 2011) adalah dimensi ritual, yaitu perilaku yang dilakukan seseorang sebagai pembuktian atas kepercayaan terhadap agamanya. Salah satu bentuknya adalah melakukan ibadah wajib shalat lima waktu serta menjalankan aturan agama.

Berbagai macam intervensi telah dilakukan untuk mencegah terjadinya perilaku seksual pranikah seperti psikoedukasi berbasis kognitif perilakuan yang dirancang oleh Fadhilah (2010), psikoedukasi kesehatan reproduksi dan psikoedukasi pendidikan seks islami oleh Wanodya (2013), pelatihan asertivitas oleh Nasri (2013). Namun demikian, prevalensi terjadinya perilaku seksual pranikah di kalangan remaja masih saja tinggi sehingga penelitian ini mencoba melakukan intervensi dari sisi religiositas khususnya ibadah shalat khusyuk. Hal ini selaras dengan hasil penelitian yang dilakukan oleh Soetjiningsih (2008), Bearman dan Bruckner (2001), Donauhue dan Benson (1995), Odimegwu (2005), Laksamana (2003), dan Meier (2003) yang mengungkapkan bahwa salah satu faktor yang memengaruhi terjadinya perilaku seksual pranikah dikalangan remaja adalah religiositas. Oleh karena itu penelitian ini bertujuan untuk mencari alternatif pemecahan masalah perilaku seksual pranikah yang terkait dengan sisi religiositas khususnya pada dimensi ritual, yaitu ibadah shalat khusuk. Dalam AlQur'an disebutkan bahwa shalat dapat mencegah atau mengurangi perilaku keji dan mungkar (QS. Al-Ankabut (29) : 45). Salah satu bentuk perilaku mungkar adalah perilaku seks pranikah. 
Sangkan (2008) memaparkan bahwa shalat merupakan ibadah yang mengarahkan jiwa kepada Allah yang membuat ruhani akan mengalami pencerahan sehingga jiwa kembali kepada kondisi bersih (fitrah) dan tidak terkontaminasi oleh dorongan-dorongan nafsu negatif. Seperti halnya dorongan seksual yang disalurkan melalui perilaku seksual pranikah, shalat merupakan salah satu cara untuk mengembalikan kesadaran jiwa, jiwa yang berserah kepada Allah, jiwa yang tunduk dan patuh, jiwa yang tercerahkan serta jiwa yang tidak terjangkau oleh pikiran negatif maupun perasaan gelisah. Dengan mendapatkan pelatihan shalat khusuk diharapkan mahasiswa dapat mengendalikan dorongan seksualnya serta tercegah dari perilaku seksual pranikah. Shalat dapat menimbulkan kesadaran dan dapat menjadi kontrol individu dalam mengendalikan nafsu dan perilaku negatif.

Dengan demikian bedasarkan latar belakang diatas hipotesis yang diajukan adalah pelatihan shalat khusuk efektif untuk menurunkan terjadinya perilaku seksual pranikah pada mahasiswa.

\section{METODE PENELITIAN}

\section{Desain Penelitian}

Rancangan eksperimen pada penelitian ini menggunakan one-group pretest-posttest design. One-group pretestposttest design adalah sebuah pengukuran prates dari konstruksi hasil desain sebelumnya. Observasi prates tunggal diambil pada sebuah kelompok responden $\left(\mathrm{O}_{1}\right)$, lalu diberikan perlakuan $(\mathrm{X})$, dan observasi pascates tunggal dengan alat ukur yang sama $\left(\mathrm{O}_{2}\right)$ berikut ini (Campbell dkk, 2002):

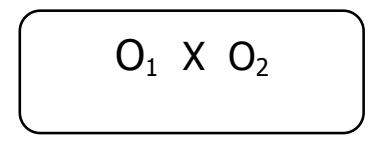

Keterangan :

$\mathrm{O}_{1}$ : Prates (sebelum diberikan perlakuan)

$\mathrm{X}$ : Perlakuan

$\mathrm{O}_{2}$ : Pascates (sesudah diberikan perlakuan)

Peneliti melakukan pengukuran terhadap peserta pelatihan sebelum dan sesudah pelatihan. Peserta diminta untuk mengisi skala prates sebelum mendapatkan perlakuan berupa pelatihan. Pada akhir sesi pelatihan, peserta diminta untuk mengisi lembar pascates. Setelah 2 minggu pelatihan, dilakukan follow up.

\section{Subjek penelitian}

Subjek penelitian ini adalah mahasiswa laki-laki dan perempuan yang berusia antara 18-24 tahun, beragama Islam, berpacaran dan melakukan aktivitas seksual dengan tingkatan sedang hingga tinggi (kencan, kissing, necking, petting, dan intercourse), memiliki tingkat shalat khusyuk dengan kategori rendah. Subjek dipilih berdasarkan kategorisasi tersebut dan ditemukan sebanyak 11 orang subjek namun dari 11 orang subjek hanya 4 orang subjek yang mengikuti pelatihan dengan lengkap sehingga data penelitian yang dapat dianalisis adalah dari 4 orang subjek saja. 


\section{Metode Pengambilan Data}

Alat ukur dalam penelitian ini menggunakan skala perilaku seksual pranikah dan skala shalat khusyuk. Skala perilaku seksual pranikah dibuat berdasarkan keluhan atau gejala-gejala yang tampak dan dilakukan oleh subjek yang ditemukan peneliti saat wawancara dan observasi. Skala perilaku seksual pranikah disusun berdasarkan The diagram group "sex: a user's manual (Soetjiningsih, 2008) dengan memper-hatikan data asesmen terhadap maha-siswa. Peneliti menyusun sendiri aitem-aitem berdasarkan bentuk-bentuk perilaku seksual pranikah yaitu (1) kencan berupa berpegangan tangan, memeluk di bahu dan memeluk di punggung, (2) Ciuman berupa ciuman pipi, kening, bibir, dan daerah erogen, (3) eksplorasi daerah genital pasangan berupa meraba alat kelamin, (4) saling meraba alat kelamin, melakukan petting dalam keadaan berpakaian, petting dalam keadaan tidak berpakaian dan (5) bersenggama.

Berdasarkan hasil uji validitas terdapat 3 aitem yang gugur dan berdasarkan dari uji reliabilitas skala perilaku seksual pranikah didapatkan koefisien alpha sebesar 0.92. Jadi, skala perilaku seksual pranikah tersebut reliabel. Kemudian skala shalat khusuk dengan mengacu kepada indikator kekhusukan shalat fardhu yang dipaparkan oleh $M$. Thalib (Musbikin, 2007), yaitu lahiriah dan batiniah. Lahiriah berupa wudhu, gerakan dan bacaan shalat, rileks dan tertib sedangkan batiniah berupa sadar Allah, tuma'ninah, sikap hormat, perasaan harap-harap cemas, serta takut dan tunduk kepada Allah, mengakui kebesarannya dan memusatkan pikiran hanya kepada Allah seakan-akan Allah berada di hadapan. Hasil uji validitas menunjukkan semua butir soal valid dengan reliabilitas skala shalat khusuk adalah 0.94 dengan nilai standar alpha sebesar 0.94. Jadi, skala shalat khusuk tersebut reliabel.

\section{Intervensi}

Rangkaian penelitian ini dimulai dengan melakukan prates kepada subjek penelitian dengan memberikan skala perilaku seksual pranikah kepada subjek penelitian. Program pelatihan dilakukan dengan metode presentasi (ceramah), diskusi dan latihan. Presentasi digunakan sebagai cara penyampaian materi. Setelah menyampaikan materi, fasilitator membuka sesi diskusi dan dilanjutkan dengan latihan. Program ini dipimpin oleh seorang seorang fasilitator dan cofasilitator, serta dibantu oleh 4 observer. Program ini dilaksanakan di kampus Universitas $X$ selama 2 hari. Pelatihan shalat khusuk terdiri atas 10 sesi dan dibagi menjadi dua kali pertemuan dengan alokasi waktu 90-140 menit setiap pertemuan. Peneliti melakukan prates sebelum pelatihan, kemudian pascates diberikan setelah pelatihan selesai pada pertemuan terakhir pelatihan tersebut. Setelah 2 minggu pelatihan selesai, dilakukan follow up.

Beberapa alat dan materi yang digunakan untuk menunjang proses penelitian adalah sebagai berikut:

1. Lembar informed concent, yaitu berisi prosedur, manfaat, resiko, hak dan 
kewajiban dan kerahasiaan identitas subjek selama menjalani pelatihan.

2. Skala perilaku seksual pranikah digunakan untuk mengukur perilaku seksual pranikah subjek sebelum dan sesudah diberikan pelatihan.
3. Modul pelatihan shalat khusuk

4. Lembar evaluasi diisi oleh subjek setelah rangkaian proses pelatihan selesai.

Berikut blue print rancangan pelatihan shalat khusuk

Tabel 1. Sesi pelatihan pelatihan shalat khusuk

\begin{tabular}{|c|c|c|c|}
\hline Pertemuan & Sesi & Kegiatan & Waktu \\
\hline \multirow[t]{7}{*}{ I } & I & a. Pembukaan dan perkenalan & 15 menit \\
\hline & & b. Penjelasan kontrak dan tujuan pelatihan & \\
\hline & II & $\begin{array}{l}\text { a. Pemberian materi Psikoedukasi tentang shalat } \\
\text { khusuk }\end{array}$ & 30 menit \\
\hline & & $\begin{array}{l}\text { b. Sharing pengalaman mengenai shalat yang } \\
\text { dijalankan sehari-hari (evaluasi shalat) }\end{array}$ & \\
\hline & III & $\begin{array}{l}\text { a. Pemberian materi Psikoedukasi "Menggapai } \\
\text { shalat khusuk" }\end{array}$ & 30 menit \\
\hline & IV & a. Diskusi, sharing dan praktek shalat I & 90 menit \\
\hline & & b. Penutupan pelatihan hari I oleh Co Fasilitator & \\
\hline \multirow[t]{6}{*}{ II } & I & a. Pembukaan dan Review & 15 menit \\
\hline & II & a. Menonton video edukasi "Sifat Shalat Nabi" & 30 Menit \\
\hline & III & a. Latihan berwudhu & 120 menit \\
\hline & & b. Latihan gerakan dan bacaan shalat & \\
\hline & & c. Latihan Dzikir dan Doa & \\
\hline & IV & $\begin{array}{l}\text { a. Diskusi, Sharing dan Refleksi } \\
\text { b. Kesimpulan dan Penutupan }\end{array}$ & 60 menit \\
\hline
\end{tabular}

\section{Teknik Analisis Data}

Analisis data penelitian dilakukan secara kuantitatif dan kualitatif. Kuantitatif menggunakan SPSS 17. Teknik analisis yang digunakan untuk menguji hipotesis dalam penelitian ini adalah dengan analisis statistika paired sample t-test. Untuk melihat perbedaan perilaku seksual pranikah subjek sebelum dan sesudah dilakukan pelatihan shalat khusuk. Sedangkan analisis kualitatif menggunakan metode wawancara dan observasi. Analisis data kualitatif bertujuan untuk melihat refleksi dan menjelaskan dinamika psikologis proses pelatihan yang terjadi pada peserta yang dapat mendukung analisis kuantitatif yang telah dilakukan sebelumnya.

\section{HASIL PENELITIAN}

\section{Hasil Pengukuran Deskriptif}

Berdasarkan tabel skala perilaku seksual pranikah diperoleh skor hipotetik, yaitu skor minimal $(\mathrm{Xmin})=0$, skor maksimal $($ Xmaks $)=102$, mean 51, dan 
standar deviasi 17 pada prates, pascates dan follow up. Skor empirik yang diperoleh pada prates adalah skor minimal $(\mathrm{Xmin})=50$, skor maksimal $($ Xmaks $)=62$ mean $=54$, dan standar deviasi $=$ 5.5. Skor empirik pascates adalah skor minimal $(X \min )=33$, skor maksimal $($ Xmaks $)=42$ mean $=37.3$, dan standar deviasi $=3.8$. Sedangkan skor follow up diperoleh skor minimal $(X \min )=22$, skor maksimal $($ Xmaks $)=$ 37, mean $=30.3$ dan standar deviasi $=$ 6.2 .

Tabel 2. Deskripsi Data Penelitian

\begin{tabular}{ccccccccc}
\hline Variabel & \multicolumn{4}{c}{ Skor Hipotetik } & \multicolumn{3}{c}{ Skor Empirik } \\
\cline { 2 - 9 } & Xmin & Xmax & Mean & SD & Xmin & Xmax & Mean & SD \\
\hline Prates & 0 & 102 & 51 & 17 & 50 & 62 & 54 & 5.5 \\
Pascates & 0 & 102 & 51 & 17 & 33 & 42 & 37.3 & 3.8 \\
Follow up & 0 & 102 & 51 & 17 & 22 & 37 & 30.3 & 6.2 \\
\hline
\end{tabular}

\section{Hasil Uji Hipotesis}

Berdasarkan hasil uji hipotesis menggunakan analisis statistika wilcoxon signed rank Dari data prates dan pascates skala perilaku seksual pranikah subjek diketahui nilai $Z$ sebesar -1.826 dengan sig 0,068 (nilai sig $>0,05$ ), yang berarti hipotesis diterima. Dengan demikian, dapat dikatakan bahwa ada perbedaan yang bermakna perilaku seksual subjek sebelum dan sesudah diberikan pelatihan shalat khusuk. Mean dari skala perilaku seksual pranikah subjek pada saat prates adalah sebesar 54 dan mean skala perilaku seksual pranikah pada saat pascates adalah 37.25, data ini menunjukkan adanya penurunan perilaku seksual pranikah pada saat pascates.

\section{PEMBAHASAN}

Berdasarkan hasil analisis data pengukuran skala perilaku seksual pranikah pada data prates dan pascates diketahui nilai Z sebesar -1.826 dengan sig 0,068 (nilai sig $>0,05$ ), yang berarti hipotesis diterima. Hal ini menunjukkan bahwa pelatihan shalat khusuk efektif untuk mengubah perilaku seksual pranikah. Ada perbedaan yang bermakna perilaku seksual subjek sebelum dan sesudah diberikan pelatihan shalat khusuk. Mean dari skala perilaku seksual pranikah subjek pada saat prates adalah sebesar 54 dan mean skala perilaku seksual pranikah pada saat pascates adalah 37.25, data ini menunjukkan adanya penurunan perilaku seksual pranikah pada saat pascates. Berdasarkan data mean hipotetik dan mean empirik saat pascates yaitu mean empirik : mean hipotetik $=37.3: 51$ dan saat follow up mean empirik : mean hipotetik $=30.3$ : 51. Kedua data tersebut menunjukkan bahwa hipotesis dan teori diterima. Ringkasnya adalah pelatihan shalat khusuk memberikan pengaruh dan efektif untuk menurunkan perilaku seksual pranikah pada mahasiswa Universitas X. 
Hasil penelitian menunjukkan bahwa pelatihan shalat khusuk memiliki pengaruh yang bermakna terhadap penurunan perilaku seksual pranikah pada mahasiswa. Hal ini terlihat dari perbedaan rerata (mean) perilaku seksual pranikah dan shalat khusuk antara prates dan pascates subjek. Rerata (mean) prates perilaku seksual pranikah adalah 54, dan pada pascates 37.3. Dari hasil tersebut terlihat bahwa rerata (mean) perilaku seksual pranikah mengalami penurunan pada saat pascates.

Berdasarkan hasil analisis tambahan dapat disimpulkan bahwa pelatihan shalat khusuk dapat menurunkan perilaku seksual pranikah dan meningkatkan shalat khusuk seluruh subjek penelitian. Kemudian pelatihan shalat khusuk dapat menurunkan perilaku seksual pranikah pada setiap aspek, yaitu aspek kencan, aspek ciuman, aspek eksplorasi genital dan aspek bersenggama. Hal ini terlihat dari seluruh subjek yang mengalami penurunan skor pada setiap aspek. Namun aspek perilaku seksual pranikah yang paling banyak mengalami penurunan poin adalah pertama pada aspek eksplorasi genital yaitu pada subjek YD yang mengalami penurunan poin sebanyak 12 poin. Kedua pada aspek berkencan, di mana seluruh subjek mengalami penurunan poin cukup banyak dan rata, antara 5 hingga 7 poin. Ketiga aspek ciuman dengan penurunan poin berkisar antara 3 hingga 6 poin dan dan keempat aspek senggama sebanyak 2 poin. Sedangkan pada peningkatan shalat khusuk seluruh subjek mengalami peningkatan shalat khusuk. Subjek yang mengalami pening- katan skor paling tinggi adalah subjek RG dan YD yaitu kenaikan 19 poin, diikuti dengan subjek PJ dan AG yang mengalami kenaikan sebanyak 16 poin. Selanjutnya penurunan perilaku seksual pranikah pada subjek laki-laki dan perempuan tidak memiliki perbedaan yang cukup jauh. Baik subjek laki-laki dan perempuan mengalami penurunan skor perilaku seksual pranikah. Penurunan berkisar dari kategori sedang hingga rendah. Pada fase tindak lanjut tingkat perilaku seksual semua subjek laki-laki dan perempuan berada pada kategori rendah.

Hasil penelitian membuktikan bahwa pelatihan shalat khusuk dapat menurunkan perilaku seksual pranikah pada mahasiswa Universitas $X$. Penurunan perilaku seksual pranikah disebabkan adanya peningkatan ibadah shalat menjadi lebih khusuk pada subjek. Subjek yang melakukan shalat dengan lebih khusuk menjadi mampu mengendalikan dorongan nafsu seksual untuk bertemu dan berduaan dengan pacar. Dengan meningkatnya ibadah shalat subjek menjadi lebih khusuk membuat subjek terhindar dari perbuatan yang melanggar ajaran agama khususnya perbuatan zina. Subjek dalam penelitian ini menyatakan bahwa perilaku seksual pranikah salah satunya disebabkan oleh kurang bisanya mengontrol nafsu dorongan seksual dan berduaan dengan pacar.

Hasil penelitian ini memperkuat penelitian Andisti dan Ritandiyono (2008) yang menyatakan bahwa ada hubungan religiositas dan perilaku seksual pranikah pada masa dewasa awal. Semakin tinggi 
religiositasnya maka semakin rendah perilaku seks bebasnya. Hasil penelitian ini juga mendukung hasil penelitian Soetjiningsih (2008) yang menunjukkan ada pengaruh langsung negatif religiositas terhadap perilaku seks pranikah remaja, yang bermakna tingginya tingkat religiositas remaja maka makin rendah perilaku seksual pranikahnya dan mendukung penelitian-penelitian sebelumnya yang membuktikan bahwa tingginya religiositas remaja memengaruhi tidak dilakukannya atau penundaan perilaku seksual pranikah (Bearman \& Bruckner, 2001).

Selain itu hasil penelitian ini sejalan dengan tinjauan beberapa studi lainnya yang menunjukan bahwa religiositas mempunyai kaitan dengan penundaan terjadinya hubungan seksual pada remaja. Penelitian Odimegwu (2005), Laksamana (2003), dan Meier (2003) menunjukkan bahwa religiositas merupakan faktor yang sangat penting dalam memprediksi sikap dan perilaku seksual pranikah. Donauhue dan Benson (1995) juga menyatakan bahwa religiositas mengurangi kemungkinan terjadinya perilaku seksual pranikah remaja sebanyak 50\%. Sementara itu Frank dan Kendall (2001) mengungkap di mana remaja yang memiliki tingkat religiositas yang tinggi mempunyai strategi pertahanan yang lebih baik sehingga cenderung menolak terlibat dalam perilaku-perilaku beresiko termasuk perilaku seksual. Religiositas merupakan faktor pencegah yang kuat untuk perilaku bunuh diri, penggunaan alkohol, perilaku seksual dan kekerasan interpersonal di masa remaja. (Donahue \& Benson, 1995).
Selanjutnya hasil penelitian ini juga memperkuat teori yang dipaparkan oleh Sangkan (2008) yang menyebutkan bahwa shalat merupakan ibadah yang mengarahkan jiwa kepada Allah yang membuat ruhani akan mengalami pencerahan sehingga jiwa kembali kepada kondisi bersih (fitrah) dan tidak terkontaminasi oleh dorongan-dorongan nafsu negatif yang ditimbulkan oleh aktivitas tubuh (id) seperti halnya dorongan seksual. Shalat yang benar dan dilakukan dengan khusyu' memiliki sifat mencegah perbuatan keji dan mungkar yang akan termanifestasikan dalam kebaikan akhlak (Sangkan, 2008). Dengan demikian shalat yang dilakukan dengan benar dan khusyu dapat mencegah manusia dari perbuatan keji dan mungkar, salah satunya adalah perilaku seksual pranikah yang menjadi trend remaja yang merupakan perbuatan zina. Dengan tercegah dari perilaku seksual pranikah. mendapatkan pelatihan shalat khusuk diharapkan mahasiswi dapat mengen-dalikan dorongan seksualnya serta Shalat dapat menimbulkan kesadaran dan dapat menjadi kontrol individu dalam mengendalikan nafsu dan perilaku negatif.

Hal ini selaras dengan yang diungkapkan oleh Ajzen (1991) bahwa shalat khusuk dapat dijadikan perceived behavioral control dalam mengendalikan perilaku seksual pranikah dan memperbaiki norma subjektif yang salah pada diri subjek. Perceived behavioral control menunjuk suatu derajat di mana seorang individu merasa bahwa tampil atau tidaknya suatu perilaku yang dimaksud adalah di bawah pengendaliannya. Per- 
ceived behavior control merupakan persepsi mengenai kontrol yang dimiliki untuk melakukan perilaku (Ajzen, 1991). Dalam kaitannya dengan perilaku seksual pranikah, jika seseorang remaja/individu memiliki kontrol yang kuat dan memiliki keyakinan bahwa kontrol tersebut mampu mengendalikan perilaku untuk tidak dilakukan maka perilaku seksual pranikah tidak akan terjadi meskipun remaja/ individu memiliki sikap dan norma subjektif yang positif (menganggap seks merupakan suatu hal yang wajar). Di sinilah peran dari shalat khusuk sebagai media untuk meningkatkan kontrol yang berasal dari dalam diri dan luar diri seperti takut kepada Tuhan, perasaan bersalah, dosa, malu, ejekan masyarakat, dan lain-lain.

Shalat khusuk juga dapat memperbaiki kesalahan norma subjektif subjek sehingga memengaruhi perilaku seksual pranikah subjek. Shalat khusuk diharapkan juga dapat meningkatkan kontrol yang dimiliki untuk menentukan perilaku. Perceived behavior control dapat memengaruhi perilaku secara langsung atau tidak langsung melalui intensi (Ajzen, 1991). Jika individu memiliki keyakinan kontrol yang kuat terhadap perilaku seks maka individu akan memiliki persepsi yang kuat dalam mengontrol perilaku, sehingga kontrol tersebut dapat langsung mengendalikan perilaku tanpa memperhatikan sikap ataupun norma subjektif.

Berdasarkan penjelasan di atas, maka dapat disimpulkan bahwa pelatihan shalat khusuk telah meningkatkan pengetahuan dan keterampilan shalat subjek penelitian menjadi lebih khusuk sehingga berpengaruh terhadap kontrol perilaku seksual pranikah subjek, dimana subjek menjadi lebih mampu mengen-dalikan dorongan nafsu seksual untuk bertemu dan berduaan dengan pacar. Dengan meningkatnya ibadah shalat subjek menjadi lebih khusuk dan menurunkan perilaku seksual pranikah subjek.

\section{SIMPULAN DAN SARAN}

\section{Simpulan}

Berdasarkan hasil analisis dapat disimpulkan bahwa pelatihan shalat khusuk berdampak positif terhadap penurunan perilaku seksual pranikah pada mahasiswa Universitas X. Mahasiswa Universitas $X$ yang mendapatkan pelatihan shalat khusuk mengalami penurunan perilaku seksual pranikah. Penurunan perilaku seksual pranikah subjek disebabkan oleh subjek mampu menerapkan shalat khusuk dalam ibadah shalat sehari-hari.

Pelatihan shalat khusuk dapat menurunkan seluruh aspek perilaku seksual pranikah yaitu dalam aspek kencan, aspek ciuman, aspek eksplorasi genital dan aspek bersenggama. Pengaruh yang paling tinggi adalah pada aspek eksplorasi genital, diikuti aspek kencan, aspek ciuman dan aspek bersenggama.

\section{Saran}

Ada beberapa saran yang hendak peneliti berikan. Pertama: Bagi subjek penelitian. Melaksanakan ibadah shalat dengan khusuk dapat menjadi fondasi untuk mencegah perilaku seksual pranikah dalam relasi pacaran pada 
mahasiswa Universitas X. Diharapkan subjek penelitian dapat menerapkan shalat khusuk seterusnya agar terbentengi dari perilaku seksual pranikah dan perilaku negatif lainnya. Kedua: Bagi pihak Universitas X. Pihak Unversitas dapat memberikan program pelatihan shalat khusuk kepada mahasiswa secara rutin agar dapat membentengi mahasiswa terhadap perilaku negatif khususnya perilaku seksual pranikah. Ketiga: pihak Universitas hendaknya bekerja sama dengan pihak rumah kos dan pihak terkait yang terdapat di sekitar kampus agar lebih ketat dalam mengatur kedisiplinan rumah kos dalam mengatur penerimaan tamu

Keempat: saran bagi peneliti selanjutnya. (1) Pada peneliti selanjutnya, pelaksanaan pelatihan shalat khusuk dapat diberikan pada seluruh mahasiswa yang berpacaran. Tidak terbatas hanya yang memiliki tingkat perilaku sedang hingga tinggi. Pelatihan shalat khusuk diberikan kepada seluruh mahasiswa yang berpacaran dan memiliki kecenderungan untuk melakukan perilaku seksual pranikah agar menjadi upaya preventif dalam mencegah perilaku seksual pranikah. Seperti kepada mahasiswa yang bertempat tinggal di rumah kost yang bebas dan sebagainya. (2) Dalam penelitian selanjutnya, pelaksanaan pelatihan shalat khusuk dapat mengikutkan mahasiswa yang berpacaran bersama-sama dengan pasangannya sehingga upaya yang dilakukan menjadi lebih efektif, yaitu dapat membentengi sepasang mahasiswa yang sedang menjalin relasi pacaran. (3) Pada materi latihan gerakan shalat sebaiknya pertemuan dilakukan lebih lama (lebih dari 2 kali pertemuan), agar peserta dapat melakukan latihan lebih banyak bersama trainer sehingga lebih menguasai. (4) Hendaknya pelatihan shalat khusuk diberikan secara berturutturut untuk menghindari lupa akan materi sebelumnya. (5) Penelitian ini hanya berfokus kepada penurunan perilaku seksual pranikah yang disebabkan oleh rendahnya tingkat religiositas khususnya pada dimensi ibadah shalat khusuk. Selanjutnya diperlukan penelitian lain yang dapat menggali aspek-aspek lain yang dapat memengaruhi perilaku seksual remaja agar dapat memberikan intervensi secara menyeluruh terhadap penurunan perilaku, seperti kondisi lingkungan rumah kos, teman sebaya, orang tua, self esteem dan lain-lain. (6) Menggunakan kelompok kontrol, sehingga penelitian menjadi lebih efektif, (7) Membangun rapport yang baik dengan subjek, sehingga subjek bisa memberikan informasi dengan jujur sesuai dengan kondisinya.

\section{DAFTAR PUSTAKA}

Ajzen, I. (1991). The Theory of Planned Behavior. Organizational Behavior and Human Decision Processes, Vol. 50, $179-211$

Ancok, D., \& Suroso, F. N. (2001). Psikologi Islami: Solusi Islam atas Problem-problem Psikologi. Yogyakarta. Pustaka Pelajar.

Bearman, P. S., \& Bruckner, H. (2001). Promising the future: Virginity pledges and the transition to first 
intercource. American Journal of Sociology, 106, 859-912.

Cook R.J., Erdman, J.N., \& Dickens, B.M. (2007). Respecting adolescents' confidentiality and reproductive and sexual choices. International Journal of Gynecology and Obstetrics, 92, 182-187.

Donahue, M. J., \& Benson, P. L. (1995). Religion and the well-being of adolescents. Journal of Social Issues, 51, 145-160.

Fadhilah. (2011). Efektivitas Psikoedukasi Berbasis Kognitif Perilakuan untuk Meningkatkan Asertivitas terhadap Perilaku Seksual Pranikah pada Remaja Perempuan di Kota P. Tesis (Tidak Diterbitkan). Yogyakarta: Universitas Islam Indonesia.

Frank, N. C., \& Kendall, S. J. (2001). Religion, Risk Prevention and Health Promotion in Adolescents: A Community Based Approach. Mental Health, Religion \& Culture, 4, 2, 133-148.

Laksamana, T. (2003). The Predictors of Sexual Behaviors and Attitudes. Perspective in psychology, spring 2003.

Maher, B. E. (2004). Abstinence until marriage: The best message for teens. The Australian family, March 2004.
Meier, A. M. (2003). Adolescent's transition to first intercource, religiosity and attitudes about sex. Social Forces, 81, 3, 1031-1053.

Musbikin, I. (2007). Rahasia Shalat Khusyu'. Yogyakarta: Mitra Pustaka.

Odimegwu, C. (2005). Influence of religion on adolescent sexual attitudes and behavior among Nigerian university student: affiliation or commitment?. African Journal of Reproductive Health, 9 (2), 125-140.

Sarwono, S.W. (2011). Psikologi Remaja. Jakarta: Grafindo.

Sangkan, A. (2008). Pelatihan Shalat Khusyu'. Jakarta: Baitul Ihsan.

Soetjiningsih, H.A. (2008). Faktor-Faktor yang Memengaruhi Perilaku Seksual Pranikah pada Remaja. Disertasi (Tidak Diterbitkan). Yogyakarta: Universitas Gajah Mada.

Suryoputro, A. (2006). Faktor-Faktor Yang Memengaruhi Perilaku Seksual Remaja di Jawa Tengah : Implikasinya Terhadap Kebijakan Dan Layanan Kesehatan Seksual dan Reproduksi. Jurnal Makara Kesehatan: Vol.10, No.1, 101-115 